\title{
"Laws of Fear" in the EU: The Precautionary Principle and Public Health Restrictions to Free Movement of Persons in the Time of COVID-19
}

\author{
Iris GOLDNER LANG*(i)
}

\begin{abstract}
COVID-19 has demonstrated the fragility of EU free movement rules when we are faced with an unknown virus of such magnitude and strength that it threatens our lives, health systems, economies and society. The aim of this text is to show the dynamics between the threat of COVID-19 and the rules imposed as a response to the pandemic, which have impacted the functioning of the EU internal market and the Schengen area. The text will concentrate on the application of the precautionary principle and public health restrictions, caused by COVID-19, to free movement of persons in the EU. The analysis will lead to three conclusions. First, it will be shown that the decisions to apply free movement restrictions and the logic followed in the EU COVID-19-related documents can be viewed as a triumph of the precautionary principle. Second, it will be argued that implementing the precautionary principle has a transformative effect on the application of the principle of proportionality in EU law. Finally, it will be shown that COVID-19 has emphasised and increased the difference between the conditions for the applicability of public health restrictions when compared to restrictions based on public policy and public security grounds.
\end{abstract}

\section{INTRODUCTION}

Fear is a terrible thing. For the past several months, fear of COVID-19 has driven our behaviour and the functioning of our societies. COVID-19 has generated fear for our lives and health, and made us dread the collapse of our health systems, economies, society and the way of life that we have known. COVID-19 has also demonstrated the fragility of EU freedom of movement rules when faced with an unknown virus of such magnitude and strength, while raising the issues of power, solidarity and trust in the system. The aim of this text is to show the dynamics between the fear of COVID-19 and the rules imposed as a response to the pandemic, which have impacted the functioning of the EU internal market and the Schengen area. The text will

\footnotetext{
Faculty of Law, University of Zagreb, Croatia; email: irisgoldnerlang@gmail.com. The title of this article draws inspiration from the book by CR Sunstein, Laws of Fear: Beyond the Precautionary Principle, CUP, 2005. I am grateful to highly insightful and useful comments by Tamara Ćapeta and the anonymous reviewers. The usual disclaimer applies. of the Creative Commons Attribution-NonCommercial-NoDerivatives licence (http://creativecommons.org/licenses/by-nc$\mathrm{nd} / 4.0 /$ ), which permits non-commercial re-use, distribution, and reproduction in any medium, provided the original work is unaltered and is properly cited. The written permission of Cambridge University Press must be obtained for commercial re-use or in order to create a derivative work.
} 
concentrate on the application of the precautionary principle and public health restrictions, caused by COVID-19, to free movement of persons in the EU. The analysis will show that the decisions to apply restrictions on free movement and the logic followed in the EU COVID-19-related documents were based on the precautionary principle, whose recourse enables decision-makers to adopt and legitimise restrictive measures when "scientific information is insufficient, inconclusive or uncertain" and risks to human health are high, ${ }^{1}$ and whose implementation transforms the application of the principle of proportionality to public health restrictions on the free movement of persons in the EU.

The discussion will show that the reactions of EU Members States and EU institutions to the pandemic have led to new insights into the functioning of public health restrictions, the principle of proportionality and the precautionary principle in EU law. The analysis will enable three conclusions. First, the restrictive mobility rules adopted as a response to the pandemic and the rhetoric used in the related EU documents can be viewed as a triumph of the much-disputed precautionary principle, even though this principle was rarely expressly mentioned as such. Reliance on the precautionary approach will be supported by examining the most important EU documents on COVID-19 and by discussing the importance of science in COVID-19 policies and the interface between science and political discretion in the adoption of precautionary measures. Second, the text will problematise the application of the principle of proportionality to restrictions of free movement of persons in the EU. By linking the precautionary principle to the principle of proportionality, it will be argued that the application of the precautionary principle transforms the test of necessity, entailed within the principle of proportionality. The discussion will show that evaluating whether public health could have been equally successfully protected by less restrictive COVID-19 mobility restrictions is particularly difficult when faced with a high degree of scientific uncertainty associated with coronavirus. Finally, it will be shown that COVID-19 has emphasised and increased the difference between the conditions for the applicability of public health restrictions, when compared to restrictions based on public policy and public security grounds. Even more so, COVID-19 has forced us to reconsider our understanding of public health restrictions, as it has certain characteristics that differentiate it from other infectious diseases we have known so far.

The text will be structured in five sections. It will follow the usual methodology for analysing measures impacting the functioning of the internal market by, first, identifying the COVID-19 restrictions impacting free movement of persons in the EU, then moving to the grounds for their justification and finally discussing them from the perspective of the principle of proportionality, while linking them with the precautionary principle. Hence, following the introduction, the second section will provide a short overview of the COVID-19 measures that restrict free movement of persons in the EU and the functioning of Schengen rules. The third section will focus on the grounds for

\footnotetext{
1 According to Commission Communication, "whether or not to invoke the precautionary principle is a decision exercised where scientific information is insufficient, inconclusive, or uncertain and where there are indications that the possible effects on the environment, or human, animal or plant health may be potentially dangerous and inconsistent with the chosen level of protection" (Communication from the Commission on the precautionary principle, COM(2000) 1 final, para 1). See also Cases C-333/08 European Commission v French Republic, ECLI: EU:C:2010:44, para 93 and Case C-77/09 Gowan Comércio Internacional e Serviços Lda v Ministero della Salute, ECLI:EU:C:2010:803, para 76.
} 
justifying mobility restrictions and concentrate on the analysis of public health justifications. The section will contrast public health with public policy and public security justifications and reveal new characteristics of public health justifications that have emerged in the context of COVID-19. The fourth, central section will focus on the principle of proportionality and the precautionary principle and link the two principles together. The section will, first, show that the precautionary principle has been relied on in EU COVID-19 mobility-related documents. It will then explain the functioning of the precautionary principle in the context of the pandemic, by discussing the interface between science and politics, and, finally, it will reveal the impact of the use of the precautionary principle on the application of the principle of proportionality to COVID-19 mobility restrictions. The concluding section will summarise the findings.

\section{Identification of COVID-19 Mobility Restrictions}

Most EU Member States reacted promptly to the risk of exponential spread of coronavirus and adopted rigorous precautionary measures that resulted in unprecedented restrictions on the free movement of persons in the EU, with major consequences for the functioning of the internal market. In March 2020 almost all EU Member States unilaterally imposed a number of mobility-related measures, drastically restricting EU cross-border movement. They also enforced lockdowns, which included restrictions on intra-state non-essential movements, and temporarily closed their external borders towards third countries for most non-residents. Never in the history of the European integration, which is based on the idea of the internal market, ${ }^{2}$ has the EU been confronted with such a magnitude of restrictive measures that have called into question the viability of the internal market.

Interestingly, all mobility restrictions were adopted nationally, without being first agreed and coordinated at the level of EU institutions. ${ }^{3}$ The European Commission was initially reserved towards this idea, but soon yielded under pressure and the reality of unilateral national restrictions implemented across the Union, and started adopting a set of soft law measures aimed at coordinating national measures and emphasising the importance of non-discrimination and proportionality. ${ }^{4}$ The only exception was the closure of external borders with third countries, which was first

2 See Art 3 TEU, which lists the establishment of the internal market as one of the Union's aims.

3 For discussions on the importance of a coordinated approach towards COVID-19, and suggestions on how to improve it, see AM Pacces and M Weimer, "From Diversity to Coordination: A European Approach to COVID-19" (2020) 11(2) European Journal of Risk Regulation 283-96; and A Renda and R Catro, "Towards Stronger EU Governance of Health Threats after the COVID-19 Pandemic" (2020) 11(2) European Journal of Risk Regulation 273-82.

4 For initial reactions, see the statements of the EU Health Commissioner, Stella Kyriakides, and the EU crisis management Commissioner, Janez Lenarčič, from 24 February 2020, saying that possible border controls and travel restrictions should be "proportionate, coordinated among EU states and based on scientific advise and risk assessment", and adding that "travel or trade restrictions are not recommended by the World Health Organisation (WHO) or the ECDC at the moment" (E Sánchez Nicolás, "No risk yet to Schengen from Italy's coronavirus outbreak", EUobserver (25 February 2020) <euobserver.com/coronavirus/147543> (last accessed 15 July 2020)). Three weeks later, at a press conference held on 13 March 2020, the Commission President, Ursula von der Leyen, announced the adoption of a set of EU measures to coordinate the response to the pandemic. For an overview of the Commission's measures, see <ec.europa.eu/info/live-work-travel-eu/health/coronavirus-response/overviewcommissions-response_en $>$ (last accessed 15 July 2020). 
agreed by the European Council and then implemented by each Member State separately. ${ }^{5}$ Nevertheless, the fact that all EU measures were adopted as soft law instruments does not necessarily imply their ineffectiveness. As an example, the EU's "traffic light system" for coordinating national travel restrictions related to the pandemic has been agreed by all EU Member States and adopted as a Council Recommendation with the intention of promoting transparency, predictability and free movement in safe conditions. ${ }^{6}$

Restrictive measures in most EU Member States limited several aspects of the right to free movement and can be categorised into two groups. First, a wide majority of Schengen states imposed border checks on their intra-Schengen borders. By 15 July 2020, 17 Schengen states reintroduced internal border controls. ${ }^{7}$ Additionally, nonSchengen EU Member States strengthened their border controls towards neighbouring Member States. Consequently, in spring 2020 the whole European territory stopped being a border-control-free area, which was a strong blow to what has always been considered as one of the most notable achievements of European integration.

The second type of COVID-19 measures restricting free movement of persons in the EU were various types of travel restrictions, suspending different forms of passenger transportation - such as flights, trains, buses and maritime transport - and bans on the entry and exit ${ }^{8}$ of persons to/from national territories. ${ }^{9}$ The difference in scope and rigidity of national travel restrictions and bans resulted in a spectrum of diverse and sometimes inconsistent measures across the EU. As an example, most entry bans to

\footnotetext{
5 On 16 March 2020 the Commission adopted its Communication on temporary restriction on non-essential travel to the EU (Communication from the Commission to the European Parliament, the European Council and the Council: COVID-19: Temporary Restriction on Non-essential Travel to the EU, COM/2020/115 final, 16 March 2020). In this document, the Commission recommended the European Council to adopt a coordinated decision on the closure of external borders. The agreement was reached by the European Council the following day (Conclusions of the President of the European Council following the video conference with members of the European Council on COVID-19, 164/20, 17 March 2020). A number of other Commission Communications followed: Communication from the Commission: COVID-19: Guidance on the implementation of the temporary restriction on non-essential travel to the EU, on the facilitation of transit arrangements for the repatriation of EU citizens, and on the effects on visa policy 2020/C 102 I/02, C/2020/2050, OJ C 102I, 30 March 2020, pp 3-11; Communication from the Commission to the European Parliament, the European Council and the Council on the third assessment of the application of the temporary restriction on non-essential travel to the EU, COM/2020/399 final; Council Recommendation (EU) $2020 / 912$ of 30 June 2020 on the temporary restriction on non-essential travel into the EU and the possible lifting of such restriction, ST/9208/2020/INIT, OJ L 208I, 1 July 2020, pp 1-7.

6 Council Recommendation on a coordinated approach to the restriction of free movement in response to the COVID19 pandemic, 13 October 2020. Press release available at <www.consilium.europa.eu/en/press/press-releases/2020/10/ 13/covid-19-council-adopts-a-recommendation-to-coordinate-measures-affecting-free-movement/> (last accessed 25 November 2020).

7 For the full list of EU Member States' notification of temporary reintroduction of internal border controls, see $<$ ec. europa.eu/home-affairs/sites/homeaffairs/files/what-we-do/policies/borders-and-visas/schengen/reintroduction-bordercontrol/docs/ms_notifications_-_reintroduction_of_border_control_en.pdf $>$ (last accessed 15 July 2020). For a detailed account of national measures reintroducing internal border controls, see S Carrera and N Chun Luk, "Love thy neighbour? Coronavirus politics and their impact on EU freedoms and rule of law in the Schengen Area", CEPS Paper, No. 2020-04, April 2020. Also, for one of the first legal appraisals of travel bans, see D Thym, "Travel Bans in Europe: A Legal Appraisal (Parts I and II)”, Odysseus blog, March 2020.

8 According to the case law of the Court of Justice of the European Union, the right to free movement also entails the right to leave one's territory (see Case C-415/93 Union royale belge des sociétés de football association ASBL v JeanMarc Bosman, Royal club liégeois SA v Jean-Marc Bosman and others and Union des associations européennes de football (UEFA) v Jean-Marc Bosman, ECLI:EU:C:1995:463, paras 95-96).

9 For the list of national restrictions impacting mobility and transport, for each Member State separately, see $<$ ec. europa.eu/transport/coronavirus-response_en > (last accessed 15 July 2020).
} 
national territories excluded domestic nationals and residents, some excluded nationals, residents and persons confirmed negative for COVID-19, while others excluded nationals, residents and persons entering the national territory for "valid reasons".

\title{
III. GRoundS FOR JUSTIFYING COVID-19 MOBILITY RESTRICTIONS AND THE
}

\author{
NEED TO RECONSIDER PUBLIC HEALTH JUSTIFICATIONS
}

Member States justified the reintroduction of border controls and the imposition of travel restrictions - including entry and exit bans to/from national territories - by COVID-19. Even though one might have thought that COVID-19 is a public health justification, this seems not to be the case in relation to the reintroduction of internal border checks. Namely, the Schengen Borders Code tolerates the temporary reintroduction of internal border checks in case of a serious threat to public policy or internal security in the respective Member State. ${ }^{10}$ Border controls may be introduced for a limited period of time in the context of either a foreseeable event or an event requiring immediate attention. ${ }^{11}$ However, the Code does not expressly mention the reintroduction of internal border controls in case of threats to public health. ${ }^{12}$ Nevertheless, the European Commission seems to suggest that in an extremely critical situation, a risk posed by a contagious disease can be equated to a public policy or internal security threat. ${ }^{13}$

Unlike the Schengen Borders Code, EU Treaty and secondary law rules on the free movement of EU citizens explicitly allow the justification of national restrictions on public health grounds. ${ }^{14}$ According to the Citizens' Rights Directive, public health grounds can be relied on only for diseases with epidemic potential, as defined by the relevant instruments of the World Health Organization, and for other infectious or contagious parasitic diseases if they are the subject of protection provisions applying to nationals of the host Member State. ${ }^{15}$ There is no doubt that COVID-19 satisfies these parameters, meaning that public health grounds can be invoked as a legitimate justification for national travel restrictions and entry/exit bans.

10 Arts 25 and 28 of Regulation (EU) 2016/399 of the European Parliament and of the Council of 9 March 2016 on a Union Code on the rules governing the movement of persons across borders (Schengen Borders Code), OJ L 77, 23 March 2016, pp 1-52.

11 Schengen Borders Code, Arts 25 and 28.

12 However, the importance of border controls as a means to prevent threats to public health is mentioned in the Preamble (point 6). The Code (Art 6(1)(e)) also states that third-country nationals are granted Schengen stays provided they are not considered a threat to public health.

13 See Commission, COVID-19 Guidelines for border management measures to protect health and ensure the availability of goods and essential services, C(2020) 1753 final, 16 March 2020, point V18: "Member States may reintroduce temporary border controls at internal borders if justified for reasons of public policy or internal security. In an extremely critical situation, a Member State can identify a need to reintroduce border controls as a reaction to the risk posed by a contagious disease. Member States must notify the reintroduction of border controls in accordance with the Schengen Borders Code."

14 Art 45(3) TFEU and Art 27(1) of Directive 2004/38 on the right of citizens of the Union and their family members to move and reside freely within the territory of the Member States.

15 Art 29(1) of Directive 2004/38. 
Consequently, the COVID-19 pandemic was used as a public health justification for all types of travel restrictions and bans. ${ }^{16}$ Nevertheless, the possibility of relying on public health as a justification for restricting free movement of persons (as well as internal security justifications, in the context of internal border controls) does not give Member States carte blanche to impose any national restrictions in case of threats to public health. Restrictive measures are admissible only provided they satisfy the principles of non-discrimination and proportionality. Additionally, they cannot be used to serve economic ends. ${ }^{17}$ Finally, procedural safeguards, including the right to judicial and, where appropriate, administrative redress procedures, should apply to decisions taken on grounds of public health. ${ }^{18}$

Section IV.3 will discuss the principle of proportionality in the context of COVID-19 mobility restrictions and point to a number of problematic issues associated with the satisfaction of proportionality requirements. It will show that the scientific uncertainty associated with COVID-19 makes it extremely difficult to establish with certainty whether travel bans were proportional. Section IV.3 will also examine the proportionality of mobility corridors and point to numerous factors that need to be taken into account when considering proportionality stricto sensu. At this point, two additional points related to public health restrictions will be made.

First, the use of public health as a justification for limiting the free movement of EU citizens points to the dichotomous role of public health in the context of the pandemic. On the one hand, the application of the precautionary principle to COVID-19 policies in a number of EU documents renders public health not just a national, but an EU value - a value which, according to the Commission, has become an overriding EU priority. ${ }^{19} \mathrm{On}$ the other hand, public health is used as a national justification to limit another important EU value - free movement of persons. This is certainly not the first time that a particular national value is also recognised as an EU value. After all, the fact that public health has been accepted by EU law as one of the grounds for justifying national restrictions of free movement, confirms the fact that it has been recognised as an EU value. However, the COVID-19 pandemic has been the first time in EU history that public health has been used simultaneously by all EU Member States to justify free movement restrictions, and this is what makes reliance on this value so unique in the context of EU law. Such a dual role of public health - as an EU value and a national value used to restrict another important EU value - points to the balancing exercise that is taking

\footnotetext{
16 Guidelines for border management measures to protect health and ensure the availability of goods and essential services, C(2020) 1753 final, 16 March 2020, points I.4. and III.11: Communication from the Commission: Towards a phased and coordinated approach for restoring freedom of movement and lifting internal border controls: COVID-19, 2020/C 169/03, C/2020/3250, OJ C 169, 15 May 2020, pp 30-37, point I (Introduction).

17 Art 27(1) of Directive 2004/38/EC of the European Parliament and of the Council of 29 April 2004 on the right of citizens of the Union and their family members to move and reside freely within the territory of the Member States, OJ L 158, 30 April 2004, pp 77-123.

18 Art 31(1) of Directive 2004/38.

19 In its Communication, the Commission stated: "The protection of public health has become the overriding priority for both the EU and its Member States" (Communication from the Commission to the European Parliament, the European Council and the Council on the third assessment of the application of the temporary restriction on nonessential travel to the EU, COM/2020/399 final). Similarly, in its Conclusions on COVID-19, the European Council stated provided: "The priority is the health of our citizens" (Conclusions of the President of the European Council following the video conference with members of the European Council on COVID-19, 164/20, 17 March 2020).
} 
place in the context of the pandemic. The EU aims to protect both public health and free movement interests, which are mutually exclusive: the more public health is protected by imposing national travel restrictions and bans, the less free movement there is. On the other hand, the choice of national precautionary measures restricting free movement of persons shows that Member States take the view that the more free movement is allowed, the more public health is jeopardised.

Second, COVID-19 has emphasised and increased the difference between the conditions for the applicability of public health restrictions, when compared to public policy and public security restrictions. Even more so, COVID-19 has forced us to reconsider our understanding of public health restrictions, due to the fact that it has certain characteristics that differentiate it from other infectious diseases we have known in the past. Certain differences between public health restrictions, on the one hand, and public policy and public security restrictions, on the other hand, are visible in the Citizens' Rights Directive. First, whereas the Citizens' Rights Directive determines which diseases justify public health restrictions, it does not give similar guidance on public policy and public security justifications. Nevertheless, the three justifications do not impose on Member States a uniform set of values. ${ }^{20}$ Member States are tolerated a certain area of discretion when determining the scope of these concepts, as long as they comply with EU law. ${ }^{21}$ As reiterated in the Commission Communication on the special measures concerning the movement and residence of citizens of the Union, which are justified on grounds of public policy, public security or public health, "Member States are free to determine the scope of [public policy, public security and public health] on the basis of their national legislation and case law, but within the framework of Community law". ${ }^{22}$

Most importantly, the Citizens' Rights Directive expressly provides that measures taken on grounds of public policy and public security have to be based "exclusively on the personal conduct of the individual concerned". ${ }^{23}$ They cannot be based on general preventive grounds ${ }^{24}$ or be automatic or systematic. ${ }^{25}$ The Court of Justice has, on several occasions, pointed out that measures justified by public policy and public security grounds may be taken only following a case-by-case assessment, ${ }^{26}$ but

\footnotetext{
20 In PI, in the context of public security restrictions, the Court pointed out that "European Union law does not impose on Member States a uniform scale of values as regards the assessment of conduct which may be considered to be contrary to public security" (Case C-348/09 PI v Oberbürgermeisterin der Stadt Remscheid, ECLI:EU:C:2012:300).

21 In Van Duyn, in the context of public policy, the Court stated: that "the particular circumstances justifying recourse to the concept of public policy may vary from one country to another and from one period to another, and it is therefore necessary in this matter to allow the competent national authorities an area of discretion within the limits imposed by the treaty" (Case 41/74 Yvonne van Duyn v Home Office, ECLI:EU:C:1974:133, para 18).

22 Communication from the Commission to the Council and the European Parliament on the special measures concerning the movement and residence of citizens of the Union that are justified on the grounds of public policy, public security or public health, COM/99/0372 final, point. 3.1.1.

23 Art 27(2) of the Citizens' Rights Directive.

24 Case 67/74 Carmelo Angelo Bonsignore v Oberstadtdirektor der Stadt Köln, ECLI:EU:C:1975:34, para 7.

25 Case C-348/96 Criminal proceedings against Donatella Calfa, ECLI:EU:C:1999:6, paras 25-27; Case C-408/03 Commission v Belgium, ECLI:EU:C:2006:192, paras 68-72.

26 Case C-331/16 K v Staatssecretaris van Veiligheid en Justitie and HF v Belgische Staat, ECLI:EU:C:2018:296, para 52; Case C-371/08 Nural Ziebell v Land Baden-Württemberg, ECLI:EU:2011:809, para 82.
} 
neither the Citizens' Rights Directive, nor the Court has stated that the same case-by-case assessment applies to measures justified on public health grounds. Interestingly, the Commission 1999 Communication on Directive 64/221 provides that "Member States may not set any general requirement that before entry into the country citizens of another Member State need to provide proof that they are not suffering from any illness mentioned in the Annex [of the Directive]". ${ }^{27}$ However, Member States' practice of requiring documents certifying that the individual entering the country has a negative coronavirus test is not in conflict with this statement, as it is not a "general" but a "specific" requirement, which obliges individuals to certify that they do not have COVID-19: they need not prove that they are not carrying any other disease with epidemic potential.

Additionally, the Communication provides that "the public health grounds are somewhat outdated given the current level of integration of the European Union and the development of new means to handle public health problems" and continues, "therefore, restrictions of free movement can no longer be considered as necessary and effective means of solving public health problems". ${ }^{28}$ Even though the 1999 Communication refers to Directive 64/ 221, which was repealed by the Citizens' Rights Directive, the Commission 2009 Guidance on the Citizens' Rights Directive confirms that "the content of the 1999 Communication is still generally valid". ${ }^{29}$ Unfortunately, the 2009 Guidance does not provide any further guidance on the use of public health justifications.

The COVID-19 pandemic has shown that public health restrictions are still important and necessary and that they cannot always be based on individual threats and case-bycase assessment. Coronavirus has symptoms and is transmitted and spreads in a way that is different from other infectious diseases we have known so far. Consequently, public health restrictions could not be based on individualised risk assessment - by considering each individual separately, based on visible symptoms or the fact that the person has had a confirmed exposure to coronavirus. COVID-19 has triggered the adoption of much more general and systematic restrictions, encompassing millions of individuals within certain regions or states, without regard to confirmed infection or exposure to coronavirus. The question whether more targeted restrictions, such as those based on widespread testing and mass screening, could achieve the same degree of public health protection is linked to the issue of proportionality of the adopted restrictions, which will be discussed below. Unless or until such methods start being used, COVID-19 will continue to showcase as a disease that has increased the gap between public health and public policy/security justifications by completely stepping out of individualised risk assessment and case-by-case approaches.

\footnotetext{
27 Communication from the Commission to the Council and the European Parliament on the special measures concerning the movement and residence of citizens of the Union that are justified on grounds of public policy, public security or public health, COM/99/0372 final, point 3.1.3.

28 ibid, point 3.1.3.

29 Communication from the Commission to the European Parliament and the Council on guidance for better transposition and application of Directive 2004/38/EC on the right of citizens of the Union and their family members to move and reside freely within the territory of the Member States, COM/2009/0313 final, point 3.
} 


\section{THE PRECAUTIONARY PRINCIPLE AND THE PROPORTIONALITY OF COVID-19}

\section{MOBILITY RESTRICTIONS}

The previous section confirmed that public health can be invoked as a legitimate justification for COVID-19 mobility restrictions. However, as stated previously, national restrictions are only admissible provided they satisfy the principle of proportionality. The aim of this section is to problematise the application of the principle of proportionality to COVID-19 free movement restrictions and link it to the use of the precautionary principle by suggesting that reliance on the precautionary principle in the adoption of restrictive measures transforms the application of the principle of proportionality. After a short introduction about the uniqueness of the application of the precautionary principle to COVID-19 in the following paragraphs, section IV.1 will reveal that the precautionary principle has been relied on in the EU COVID-19 mobility-related documents. Section IV.2 will explain the functioning of the precautionary principle in the context of the pandemic by discussing two crucial components of the precautionary approach towards COVID-19: scientific risk assessment of COVID-19 and its political risk management. Section IV.3 will link the findings about the use of the precautionary principle in COVID-19 mobility policies to the principle of proportionality by discussing the impact of the use of the precautionary principle on the proportionality of COVID-19 free movement restrictions.

In short, the precautionary principle allows decision-makers to adopt restrictive measures when potentially dangerous effects deriving from a phenomenon, product or process for the environment, human, animal or plant health have been identified and scientific evidence about the risk are insufficient, inconclusive or uncertain. ${ }^{30}$ As will be displayed, the EU

30 According to the Communication from the Commission on the precautionary principle (COM(2000) 1 final, para 4), "recourse to the precautionary principle presupposes that potentially dangerous effects deriving from a phenomenon, product or process have been identified, and that scientific evaluation does not allow the risk to be determined with sufficient certainty". The Communication further elaborates (para 3) that precautionary principle covers "those specific circumstances where scientific evidence is insufficient, inconclusive or uncertain and there are indications through preliminary objective scientific evaluation that there are reasonable grounds for concern that the potentially dangerous effects on the environment, human, animal or plant health may be inconsistent with the chosen level of protection".

There is no single universal or EU-wide definition of precautionary principle. Different versions exist at the international, EU and national levels. Definitions mainly vary depending on the degree of scientific uncertainty needed to trigger the application of precautionary principle, the level of commitment it creates on the side of decision-makers and the level of seriousness of the potential hazard. Apart from the European Commission, UN (Rio Declaration) and the European Environmental Agency have put forward their definitions. In addition, the Court of Justice has developed its interpretation of precautionary principle, which is consistent with the definition put forward by the Commission Communication, In its BSE case, the Court established that "where there is uncertainty as to the existence or extent of risks to human health, the institutions may take protective measures without having to wait until the reality and seriousness of those risks become fully apparent" (Cases C-180/96 UK v Commission, ECLI:EU:C:1998:192, para 99; C-333/08 European Commission v French Republic, ECLI:EU:C:2010:44, para 91 and Case C-77/09 Gowan Comércio Internacional e Serviços Lda v Ministero della Salute, ECLI:EU:C:2010:803, para 73).

There is rich literature on precautionary principle in the EU. Some valuable writings contributions include: A Alemanno, "The Shaping of the Precautionary Principle by European Courts: From Scientific Uncertainty to Legal Uncertainty", Bocconi Legal Studies Research Paper no 1007404, 2007; M Feintuck, "Precautionary Maybe, But What's the Principle? The Precautionary Principle, the Regulation of Risk, and the Public Domain" (2005) 32 Journal of Law and Society 371-98; EC Fisher (2007) Risk: Regulation and Administrative Constitutionalism (Hart Publishing 2007) Chapter 6; G Majone, "The precautionary principle and its policy implications" (2002) 40(1) Journal of Common Market Studies 89-109; J Scott and E Vos, "The juridification of uncertainty: Observations on the ambivalence of the precautionary principle within the EU and the WTO", in C Joerges and R Dehousse (eds) Good Governance in Europe's Integrated Market (OUP 2002) pp 253-86; K Steele, "The Precautionary Principle: A New Approach to Public Decision-Making" 5(1) (2006) Law, Probability and Risk 19-31; J Zander, The Application of the Precautionary Principle in Practice: Comparative Dimensions (CUP 2010). 
(and worldwide) approach towards the COVID-19 pandemic can be viewed as a triumph and regeneration of the previously much-disputed precautionary approach. Even one of the most fierce US critics of the precautionary principle has openly admitted that it is absolutely justified in the face of scientific uncertainty linked to COVID-19. ${ }^{31}$

COVID-19 policies in the EU are the first policies in which the precautionary principle has been applied to such an extent and with such severity as to restrict the free movement of persons, in response to a communicable disease. ${ }^{32}$ Even though restrictive measures affecting free movement of persons in the EU were also imposed to prevent the spread of SARS in 2003, the measures enacted 17 years ago are incomparable to the ones adopted in 2020, in terms of both their scope and their rigidity. ${ }^{33}$ The COVID-19 pandemic is also one of the rare cases in which the precautionary principle has been used not as a method to consider risks that might be incurred by acting (for example by putting a new product on the market), but the ones that would result from non-acting, i.e. from not imposing restrictions on free movement.

\section{The precautionary principle in EU COVID-19 mobility-related documents}

Even though EU documents related to COVID-19 rarely expressly mention the precautionary principle, there is no doubt that EU institutions have endorsed the precautionary approach by tolerating and approving national restrictions to free movement of persons and Schengen, and by implicitly acknowledging the precautionary approach. The analysis of key Commission and Council documents on COVID-19 mobility policies from spring and summer 2020 reveals that only one of

31 CR Sunstein, one of the leading critics of the precautionary principle (see CR Sunstein, Laws of Fear: Beyond the Precautionary Principle (CUP 2005)), admitted it was justified in relation to COVID-19 (see CR Sunstein, "This Time the Numbers Show We Can't Be Too Careful”, 26 March 2020 (Bloomberg)). For Sunstein's criticism of the precautionary principle, see CR Sunstein, Laws of Fear.

32 The EU-level application of the precautionary principle up until the emergence of COVID-19 reveals that it has been used in situations of scientific uncertainty linked to different types of risks. In the early years, it was, first implicitly and then openly, applied to environmental risks such as climate change, fish stock management, genetically modified organisms, the use of antimicrobials as growth promoters, etc. For the implicit reliance on the precautionary principle of the area of environment, see the EU's Environmental Action Programme from 1973 (Declaration of the Council of the European Communities and of the representatives of the Governments of the Member States meeting in the Council of 22 November 1973 on the programme of action of the European Communities on the environment, OJ C 112, 20 December 1973, pp 1-53, para C1). On the other hand, the EU's Environmental Action Plan from 1987 explicitly mentioned precaution (Resolution of the Council of the European Communities and of the representatives of the Governments of the Member States, meeting within the Council of 19 October 1987 on the continuation and implementation of a European Community policy and action programme on the environment (1987-92), OJ C 328, 7 December 1987, pp 1-44, paras 4.4.3 and 4.4.8). The precautionary principle was inserted in EU Treaties by the Treaty of Maastricht, stating that "Community policy on the environment ... shall be based on the precautionary principle (then Art 130r(2), now Art 191(2) TFEU). The BSE ("mad-cow disease") crisis prompted the European Commission to issue its Communication on precautionary principle and initiated the process of the introduction of precautionary principle to human health risks in different areas of EU law, such as the internal market (see Green Paper on the General Principles of Food Law in the European Union, dated 30 April 1997 (COM(97) 176 final)) and spreading to areas such as fisheries (see Regulation 1380/2013 on the Common Fisheries Policy, dated 11 December 2013); social policy (see Directive 2004/37/EC on the protection of workers from the risks related to exposure to carcinogens or mutagens at work, dated 29 April 2004); transport (see Regulation 782/2003 on the prohibition of organotin compounds on ships, dated 14 April 2003); the area of freedoms, security and justice (see Regulation 864/2007 on the law applicable to non-contractual obligations (Rome II), dated 11 July 2007) and so on.

33 For the overview of the anti-SARS measures imposed in 2003, see "Measures undertaken by Member States and Accession Countries to control the outbreak of SARS", Report by the Commission, 5 June 2003, 280503V3. So far, the precautionary principle has been applied mostly in relation to a number of different challenges, such as the environmental risks listed supra, note 32 . 
these documents makes explicit reference to the precautionary principle. This is the Joint European Roadmap towards lifting COVID-19 containment measures, which states:

the restrictive measures introduced by Member States ... have been based on available information in relation to the characteristics of the epidemiology of the disease and followed a precautionary approach,

and continues:

the Roadmap builds on the expertise and the advice provided by the European Centre for Disease Prevention and Control (ECDC) and the Commission's Advisory Panel on COVID-19 and takes into account the experience and outlook from a number of Member States as well as guidance from the World Health Organization (WHO). ${ }^{34}$

The Roadmap also, on several occasions, states that it is "based on science", thus acknowledging the importance of scientific risk assessment for COVID-19 political decision-making. As explained in the subsequent sections, scientific evaluation is a necessary, integral part of the precautionary approach. Consequently, this wording of the Roadmap has a dual effect: it supports the reference the Roadmap makes to the precautionary approach and confirms that Member States' actions must be supported by scientific evidence in order to be proportionate.

Other EU COVID-19 mobility-related documents from spring and summer 2020 do not make explicit reference to the precautionary principle. However, even without explicit reference to precaution, these documents and the whole EU and Member States' approach to COVID-19 restrictions have been triggered by the concern about the risks of COVID-19 to public health and were characterised by a high degree of scientific uncertainty caused by the lack of conclusive data about the disease. The fact that a number of EU documents do not make explicit reference to the precautionary principle does not refute this conclusion. On the contrary, as confirmed by the Court of Justice in its previous case-law, "the lack of express reference to the precautionary principle ... does not mean that that institution did not rely on that principle ... in order to prevent the alleged risks". 35

Additionally, a number of EU COVID-19 mobility-related documents use a number of terms that can be associated with both proportionality analysis and the precautionary approach, such as: "protection", "preventive measures", "science", "risk assessment", "risk management", "ECDC", "WHO", and the balancing of different criteria, including the epidemiological situation, when making COVID-19 policy choices. Council Conclusions on COVID-19 from 20 February 2020 underline the importance of coordination of "contact tracing and risk communication" measures, as well as "sharing of information on national preventive and preparatory measures within the

34 Joint European Roadmap towards lifting COVID-19 containment measures, 2020/C 126/01, C/2020/2419, OJ C 126, 17 April 2020, pp 1-11.

35 Case T-392/02 Solvay Pharmaceuticals BV v Council of the European Union, ECLI identifier: ECLI:EU: T:2003:277, para 124. 
Health Security Committee and Early Warning System". ${ }^{36}$ They stress the importance of "the work of ECDC on technical guidance regarding ... risk assessment" and call upon the Commission to facilitate Member States' cooperation on "surveillance, risk assessment (and) risk management", while emphasising the importance of "scientific information" and "scientific advice from ECDC and WHO". ${ }^{37}$ Similarly, Commission Guidance on the implementation of the temporary restriction on non-essential travel to the EU and a Commission Communication on the third assessment of the application of the temporary restriction on non-essential travel to the EU emphasise the importance of reliance on ECDC's work. ${ }^{38}$ Equally, the Guidelines for border management measures to protect health and ensure the availability of goods and essential services and European Council Conclusions from 10 March 2020 rely strongly on science, while the Guidelines expressly provide that "restrictions to the transport of goods and passengers on grounds of public health" must be "sciencebased and supported by WHO and ECDC recommendations". 39

Whereas Commission Guidelines concerning the exercise of the free movement of workers during COVID-19 outbreaks do not make direct or indirect reference to precaution, science, risk assessment or other terms directly associated with the precautionary principle, they emphasise the importance of non-discrimination and proportionality as principles that have to be respected when adopting precautionary measures, as elaborated further below. ${ }^{40}$ Finally, the Commission Communication "Towards a phased and coordinated approach for restoring freedom of movement and lifting internal border controls" underlines not only the importance of ECDC's scientific advice and risk assessment, but also emphasises that "the process towards the lifting of travel restrictions and internal border controls will require the weighing and balancing of different criteria, taking into account the specific epidemiological situations in each Member State, which may in turn vary between areas and regions". ${ }^{41}$ As will be discussed further in the text, the precautionary approach in general and in the context of the COVID-19 pandemic is characterised exactly by such a balancing approach. Political decisions on COVID-19 mobility restrictions are taken by relying on scientific evaluation of the disease as a starting point, but the

\footnotetext{
36 Council Conclusions on COVID-19, 2020/C 57/04, ST/6038/2020/INIT, OJ C 57, 20.2.2020, pp 4-7, point 6.

37 Council Conclusions on COVID-19, 2020/C 57/04, ST/6038/2020/INIT, OJ C 57, 20.2.2020, pp 4-7, points 9 and 16.

38 Communication from the Commission: COVID-19: Guidance on the implementation of the temporary restriction on non-essential travel to the EU, on the facilitation of transit arrangements for the repatriation of EU citizens, and on the effects on visa policy 2020/C 102 I/02, C/2020/2050, OJ C 102I, 30 March 2020, pp 3-11; Communication from the Commission to the European Parliament, the European Council and the Council on the third assessment of the application of the temporary restriction on non-essential travel to the EU, COM/2020/399 final.

39 Guidelines for border management measures to protect health and ensure the availability of goods and essential services, C(2020) 1753 final, 16 March 2020, point 1; Conclusions of the President of the European Council following the video conference on COVID-19, 138/20, 10 March 2020.

40 Communication from the Commission: Towards a phased and coordinated approach for restoring freedom of movement and lifting internal border controls: COVID-19, 2020/C 169/03, C/2020/3250, OJ C 169, 15 May 2020, pp 30-37.

41 Communication from the Commission: Towards a phased and coordinated approach for restoring freedom of movement and lifting internal border controls: COVID-19, 2020/C 169/03, C/2020/3250, OJ C 169, 15 May 2020, pp 30-37.
} 
final political decisions on precautionary measures are taken by weighing public health concerns with social, economic and other important interests.

\section{The precautionary approach towards COVID-19}

This subsection will explain the functioning of the precautionary principle in the context of the pandemic by discussing the interface between two crucial components of precautionary approach: the scientific risk assessment of COVID-19 and its risk management. Namely, the precautionary principle takes a structured approach to the risk. The initial step - scientific risk assessment - is performed by scientists, whereas further steps - risk management and risk communication - are taken by decisionmakers. ${ }^{42}$ This subsection will show that the response to the COVID-19 pandemic reflects this interface between science and politics.

\section{a. Risk assessment of COVID-19: the importance of science}

The COVID-19 pandemic has confirmed the importance of scientific risk assessment in political decision-making in situations of high risk for human health. The EU's acceptance of Member States' COVID-19-related restrictions (as well as national decisions to impose these restrictions) has been driven by medical science. Never in human history have decision-makers and the wider public paid so much attention to the findings of epidemiologists and virologists, and laid so much trust in them. However, due to an extremely short time span since the emergence of coronavirus and so many unknowns associated with its spread, scientific findings could not be conclusive. This created a situation of scientific uncertainty, with, nevertheless, reasonable grounds for concern that the virus could create real harm to human health. ${ }^{43}$ All these factors - the performance of scientific evaluation, the existence of scientific uncertainty and the identification of negative effects for human health - are prerequisites for invoking the precautionary principle and they were all satisfied in relation to coronavirus. ${ }^{44}$

Scientific risk assessment of COVID-19 was, at the EU level, performed by the ECDC. ${ }^{45}$ The ECDC is an EU agency created in 2004 and based in Stockholm, with a mission to identify and assess risks and communicate current and emerging threats

42 According to the Commission Communication on the precautionary principle, the precautionary, structured approach to the analysis of risk "comprises three elements: risk assessment, risk management, risk communication" (Communication from the Commission on the precautionary principle, $\operatorname{COM(2000)} 1$ final, para 4).

43 The EU does not specify the degree of scientific uncertainty that needs to exist in order to trigger the application of the precautionary principle. On the other hand, Principle 15 of the Rio Declaration provides that "lack of full scientific certainty" shall not be used as a reason for postponing the adoption of precautionary measures.

44 These prerequisites for invoking the precautionary principle have been identified in the Communication from the Commission on the precautionary principle, $\operatorname{COM}(2000) 1$ final, para 5.1.3. According to the Communication, precautionary principle can be invoked only if the potential adverse effects to health or the environment of a particular phenomenon, product or process have been identified, and provided a comprehensive assessment of the risk to health or the environment has been performed based on the most reliable scientific data available and the most recent results of international research (Regulation (EC) No 851/2004 of the European Parliament and of the Council of 21 April 2004 establishing a European Centre for Disease Prevention and Control, OJ L 142, 30 April 2004, pp 1-11).

45 Regulation (EC) No 851/2004. 
to human health from communicable diseases and other sources. ${ }^{46}$ Considering the fact that the Union has only supporting competence in relation to the protection and improvement of human health, the ECDC's work complements and does not replace the work of national centres of disease control, with which it cooperates and coordinates its work. ${ }^{47}$ However, the ECDC has an important role in the pandemic, as it gathers and prepares all EU data on the pandemic and disseminates recommendations for good practice.

In addition to its cooperation with national disease control authorities, in its work, the ECDC also relies on the findings of WHO, which became particularly relevant in the ECDC's risk assessment of COVID-19. The contrast between the ECDC's and WHO's initial findings on COVID-19 and the ones published with the spread of coronavirus, accurately demonstrates the high degree of scientific uncertainty associated with this novel disease. The ECDC's first risk assessment of COVID-19 from 9 January 2020 provided that, since there was no indication of human-to-human transmission and since no cases were found outside of Wuhan, the risk of its introduction and spread within the EU was considered low to very low. ${ }^{48}$ This wording accurately shows the limited nature of scientific data on coronavirus in Europe at the beginning of January 2020. In contrast, the ECDC's risk assessment from 2 March 2020 considered that the risk associated with COVID-19 infections in the EU was "moderate to high, based on the probability of transmission and the impact of the disease". ${ }^{49}$ In the same Report, the ECDC acknowledged the existence of "significant uncertainties" in its evaluation, "due to many unknowns ... regarding the virulence/pathogenicity, the mode of transmission, the reservoir and the source of infection of COVID-19". 50

Interestingly, when advocating which measures should be used to mitigate the impact of the pandemic, neither the ECDC nor WHO initially encouraged the use of border closures and travel restrictions. In its Guidelines for the use of non-pharmaceutical countermeasures to delay and mitigate the impact of the COVID-19 pandemic, from 10 February 2020 the ECDC stated that "available evidence ... does not support recommending border closures which will cause significant secondary effects and societal and economic disruption in the EU". 51 The Guidelines further provided that

46 Art 3(1) of Regulation (EC) No 851/2004.

47 For a different approach, stating that the EU has more powers to create health law in response to COVID-19 than it has actually used, see KP Purnhagen et al, "More Competences than You Knew? The Web of Health Competence for European Union Action in Response to the COVID-19 Outbreak" (2020) 11(2) European Journal of Risk Regulation 297-306. For a suggestion that the EU COVID-19-related Guidelines (discussed in section IV.1) represent an attempt by the EU to operationalise untested competences in the area of health policy, see A Alemanno, "The European Response to COVID-19: From Regulatory Emulation to Regulatory Coordination?" (2020) 11(2) European Journal of Risk Regulation 307-16.

48 European Centre for Disease Prevention and Control, "Pneumonia cases possibly associated with a novel coronavirus in Wuhan, China”, 9 January 2020 (ECDC 2020) p 2.

49 European Centre for Disease Prevention and Control, "Outbreak of novel coronavirus disease 2019 (COVID-19): increased transmission globally - fifth update, 2 March 2020”, 2 March 2020 (ECDC 2020) p 5.

50 ibid, p 4.

51 European Centre for Disease Prevention and Control (ECDC), "Guidelines for the use of non-pharmaceutical measures to delay and mitigate the impact of 2019-nCoV", 2020, p 8. The Guidelines further refer to IHR and Directive 2004/38, by stating that border closures are regulated internationally by International Health Regulations (World Health Organization (WHO), International Health Regulations (2005), second edition (WHO 2005)) and that 
"border closures may delay the introduction of the virus into a country only if they are almost complete and when they are rapidly implemented during the early phases, which is feasible only in specific contexts (e.g. for small, isolated, island nations)". 52 The ECDC's stance on border closures was not isolated. It relied on the position of WHO, according to which "Travel bans to affected areas or denial of entry to passengers coming from affected areas are usually not effective in preventing the importation of cases but may have a significant economic and social impact". 53 The Commission acknowledged the WHO's position in its Communication on Temporary Restriction on Non-essential Travel to the EU, but, nevertheless, recommended to the European Council to close the external borders. ${ }^{54}$ The ECDC's risk assessment from 23 April 2020 still recognised that substantial uncertainty regarding the epidemiological characteristics of COVID-19 continued to persist and that the effectiveness of different measures remained unclear, since many countries around the world introduced interventions en bloc. $^{55}$ The ECDC's risk assessment on 10 August 2020 continued to emphasise that "available evidence does not support border closures", since COVID-19 "cannot be controlled by means of border closures" and that "measures to effectively contract-trace travellers crossing borders are needed and these should be reinforced in the coming period". 56

\section{b. Risk management of COVID-19: political discretion}

Despite both the ECDC's and WHO's scepticism about border closures, national responses to the COVID-19 pandemic in the EU and across the world included a high degree of travel restrictions and bans. This asymmetry between scientific findings of the European and world health organisations and national political choices reflects the functioning of the precautionary principle. Provided scientific evaluation identifies a

free movement within the EU may be limited for public health reasons within the limits set by the Treaties and in accordance with Art 29 of Directive 2004/38 (Directive 2004/38/EC on the right of citizens of the Union and their family members to move and reside freely within the territory of the Member States, OJ L 158, 30 April 2004, pp 77-123). On the other hand, the ECDC considers that broad domestic travel restrictions, within a country or region, may have a small positive impact in delaying an epidemic only if they are implemented during the early, containment phase of the epidemic.

52 European Centre for Disease Prevention and Control (ECDC), "Guidelines for the use of non-pharmaceutical measures to delay and mitigate the impact of 2019-nCoV", 2020, p 8. See also E Sánchez Nicolás, "EU experts: closing borders 'ineffective' for coronavirus", EuObserver (28 February 2020) < euobserver.com/coronavirus/ 147576> (last accessed 20 May 2020).

53 World Health Organization (WHO), Updated international recommendations for international traffic in relation to COVID-19 outbreak (29 February 2020) <www.who.int/news-room/articles-detail/updated-who-recommendationsfor-international-traffic-in-relation-to-covid-19-outbreak> (last accessed 20 May 2020).

54 In the Communication, the Commission stated that "while travel restrictions are generally not seen by the World Health Organisation as the most effective way of countering a pandemic, the rapid spread of COVID-19 makes it essential that the EU and Member States take urgent, immediate and concerted action not only to protect the public health of our populations, but also to prevent the virus from further spreading from the EU to other countries, as has been observed in recent weeks" (Communication from the Commission to the European Parliament, the European Council and the Council: COVID-19: Temporary Restriction on Non-essential Travel to the EU, COM/ 2020/115 final, 16 March 2020).

55 Coronavirus disease 2019 (COVID-19) in the EU/EEA and the UK - ninth update, 23 April 2020 (ECDC 2020) p 17.

56 Coronavirus disease 2019 (COVID-19) in the EU/EEA and the UK - eleventh update: resurgence of cases, 10 August 2020 (ECDC 2020) p 19. 
risk to human health but scientific uncertainty remains, the choice whether to adopt precautionary measures and, if so, to determine the type and degree of severity of such measures is no longer in the realm of science, but relies on political discretion. This does not mean that precautionary measures can be discretionary or based on a hypothetical risk. They need to be underpinned by sound scientific assessment of the existence of a real risk. ${ }^{57}$ However, the final decision whether and which measures to resort to, without having to wait until the seriousness of the risks to human health becomes fully apparent, lies in the hands of politicians, not scientists. ${ }^{58}$ Scientific risk assessment underpins precautionary measures, but does not predetermine their choice or type.

The response to the COVID-19 pandemic illustrates this interface between scientific evaluation and political discretion. ${ }^{59}$ In the COVID-19 world, scientific models could measure morbidity and mortality risks based on the scientific - albeit still inconclusive and uncertain - findings of coronavirus behaviour and its spread, but they could not tell us how our society wants to deal with the virus and what implications we are ready to bear. These decisions had to be taken by political leaders, who had to make a balancing exercise between risks to public health and societal risk tolerance, when deciding on COVID-19 responses. ${ }^{60}$ Ultimately, these decisions also had to be made by each individual person, when making a choice whether to go to a store (provided this was a matter of choice) or take a walk in the park. Scientific risk assessment was and continues to be performed by medical experts, whereas risk management - or choosing how to deal with these risks - lies in the hands of decision-makers, in the first place, but also in the hands of our communities (in cases where community members voluntarily decide to try to protect each other) and, ultimately, with each individual person. Political leaders had to make a choice, while taking into consideration social behaviour and attitudes to COVID-19 risks at the macro and micro levels.

Decision-makers had to make two interconnected choices. First, they had to decide whether to act or not, based on the examination of benefits and costs of action or lack of action. ${ }^{61}$ Second, in the affirmative, they had to decide on how to act, ie which

57 The precautionary principle cannot be invoked in case of a hypothetical or imaginary risk (see cases T-13//99 Pfizer Animal Health v Council, ECLI:EU:T:2002:209, para 143 and T-229/04 Kingdom of Sweden v Commission of the European Communities, ECLI:EU:T:2007:217, para 161). See also D Bourguignon, "Precautionary Principle: Definitions, applications and governance", European Parliamentary Research Service, 2015, PE 573.876, p 9.

58 As stated by the Court of Justice in Solvay Pharmaceuticals, "in the field of public health, the precautionary principle implies that, where there is uncertainty as to the existence or extent of risks to human health, the institutions may take precautionary measures without having to wait until the reality and seriousness of those risks become fully apparent" (Case T-392/02 Solvay Pharmaceuticals BV v Council of the European Union, ECLI identifier: ECLI:EU:T:2003:277, para 122).

59 On the challenges related to the interface between science and policy, see: S van den Hove, "A rationale for science-policy interfaces" Elsevier (2007) 39 Futures 807-26.

60 As stated by the Court of Justice in Pfizer, "where measures for the protection of human health are concerned, the outcome of that balancing exercise will depend ... on the level of risk which the authority deems unacceptable for society" (T-13//99 Pfizer Animal Health v Council, ECLI:EU:T:2002:209, para 161).

61 According to the Commission Communication, the examination of benefits and costs should include, where appropriate and feasible, an economic cost-benefit analysis (Communication from the Commission on the precautionary principle, $\operatorname{COM}(2000) 1$ final, para 6). However, the cost-benefit analysis is often considered to take a different approach, when compared to the precautionary principle. On the debate between the pros and costs of the precautionary principle in comparison to the cost-benefit analysis, in the context of COVID-19, see C Moran, 
precautionary measures to adopt. ${ }^{62}$ There is a general agreement that the precautionary principle does not call for specific measures - such as bans or reversing the burden of proof - or lead to a predetermined solution. In addition, there is no general agreement which method should be used to determine when to apply precautionary measures. ${ }^{63}$ This setting gave decision-makers considerable flexibility in deciding whether and which types of COVID-19 measures to apply. ${ }^{64}$ As a result, not all EU Member States chose the same approach. Unlike most Member States, which resorted to rigorous measures from the very start, Sweden opted for a more relaxed approach, including at its borders, which were not closed for EEA nationals, ${ }^{65}$ whereas the UK first chose a "herd immunity" strategy and then, under the pressure of scientific community and the wider public, switched to stricter measures. ${ }^{66}$

The differences in the Member States' approach to coronavirus show that the EU's understanding of the level of political commitment created by the precautionary principle is a medium one: the risk the virus created to human health justified but did not oblige action or dictate the type of measures to be taken. ${ }^{67}$ The EU's medium approach finds a middle ground between two extremes: between a completely noncommittal approach, contending that uncertainty does not justify inaction but nothing more than that, ${ }^{68}$ and the one where uncertainty necessitates action. ${ }^{69}$ Such a medium modus operandi is in line with the functioning of public health restrictions to the free

\footnotetext{
"A Time for Precaution: Rethinking Economics" (2020) Rethinking Economics <www.rethinkeconomics.org/journal/ a-time-for-precaution/> (last accessed 17 May 2020).

62 For the importance of the distinction between risk assessment and risk management, and between the decisions whether to act and how to act, see Commission Communication, para 5.

63 As summarised by the European Parliament Research Service, different methods include cost-benefit analysis, risk trade-off analysis, cost-effectiveness analysis, pros and cons analysis of action and inaction, etc (Bourguignon, supra, note $57, \mathrm{p} 13)$.

64 For the interpretation of the precautionary principle as an open-ended and flexible principle that helps decisionmakers to make prudent decisions, see World Commission on the Ethics of Scientific Knowledge and Technology, "The Precautionary Principle" (UNESCO 2005) p 21 < unesdoc.unesco.org/ark:/48223/pf0000139578> (last accessed 20 May 2020). However, some authors caution that the criteria for the application of the precautionary principle provided in the Commission Communication need to be followed more consistently and that the Communication needs to be updated (see R Löfstedt, "The precautionary principle in the EU: Why a formal review is long overdue" (2014) 16(3) Risk Management 149-51).

65 T Hoon Kim, "Why Sweden is unlikely to make a U-turn on its controversial Covid-19 strategy" (The Guardian, 22 May 2020) <www.theguardian.com/commentisfree/2020/may/22/sweden-u-turn-controversial-covid-19-strategy > (last accessed 23 May 2020). On the other hand, according to the Financial Times, Sweden has the highest COVID-19 death toll (see R Milne, "Sweden's death toll unnerves its Nordic neighbours" (Financial Times, 20 May 2020) $<$ www.ft.com/content/46733256-5a84-4429-89e0-8cce9d4095e4> (last accessed 29 May 2020).

66 For the critique of the "herd immunity" approach, see D Conn and P Lewis, "Documents contradict UK government stance on COVID19 'herd immunity"” (The Guardian, 12 April 2020) <www.theguardian.com/world/ 2020/apr/12/documents-contradict-uk-government-stance-on-covid-19-herd-immunity> (last accessed 23 May 2020).

67 For the classification of definitions based on the level of commitment, see JB Wiener and MD Rogers, "Comparing Precaution in the United States and Europe" (2002) 5 Journal of Risk Research 320-21.

68 For the example of a weaker definition, claiming that uncertainty does not justify inaction, see Principle 15 of the Rio Declaration, which provides that "In order to protect the environment, the precautionary approach shall be widely applied by States according to their abilities. Where there are threats of serious or irreversible damage, lack of full scientific certainty shall not be used as a reason for postponing cost-effective measures to prevent environmental degradation" (UNCED, Rio Declaration on Environment and Development (1992) UN Doc A/CONF.151/5/Rev 1, 31 ILM 874).

69 The most rigorous approach, which shifts the burden of proof, is visible in the Commission's prior approval mechanism, which requires the producer to go through a complicated procedure before the placing on the market of certain products, such as drugs, pesticides or food additives, that are considered "a priori" hazardous or are potentially hazardous at a certain level of absorption (Commission Communication on precautionary principle, para 6.4, p 20).
} 
movement of persons in the EU. As analysed in the following subsection, public health may be used as a justification for restrictions of free movement, but not at all costs: the measure is acceptable only provided it is proportionate to the public health aim it pursues.

\section{Proportionality of COVID-19 mobility restrictions}

When choosing the types of precautionary measures, decision-makers are bound by international, European and national standards. The principle of proportionality is one of the standards that has to be satisfied by precautionary measures that restrict free movement, from the perspective of both EU internal market rules and the rules on the functioning of the precautionary principle. EU internal market law renders a free movement restriction acceptable only provided it is justifiable on one of the acceptable grounds, and proportionate, meaning that it is suitable for the achievement of the desired aim, such as public health (suitability test), that the desired aim could not have been reached by a less restrictive measure (necessity test), and that the measure is reasonable, considering other competing interests and the degree of interference to free movement of persons (proportionality stricto sensu). ${ }^{70}$

On the other hand, both the Commission Communication on the precautionary principle and the related case-law of the Court of Justice set proportionality as one of the requirements that have to be satisfied by precautionary measures. ${ }^{71}$ The Communication provides a detailed list of criteria that have to be met by each precautionary measure, stating that such measures should be

proportional to the chosen level of protection, non-discriminatory in their application, consistent with similar measures already taken, based on an examination of the potential benefits and costs of action or lack of action (including, where appropriate and feasible, an economic cost/benefit analysis), subject to review, in the light of new scientific data, and capable of assigning responsibility for producing the scientific evidence necessary for a more comprehensive risk assessment. ${ }^{72}$

\footnotetext{
70 In public health case, the Court of Justice often conducts only the first two tests and leaves out proportionality stricto sensu. On the functioning of the principle of proportionality and the tests of suitability, necessity and proportionality stricto sensu it entails, see the Opinion of AG Maduro in Case C-434/04, Criminal proceedings against Jan-Erik Anders Ahokainen and Mati Leppik, ECLI:EU:C:2006:462. See also the chapter on "The Principle of Proportionality: Review of Community Measures" in T Tridimas, The General Principles of EU Law (OUP 2007); AL Young and G de Búrca, "Proportionality", in General Principles of Law: European and Comparative Perspectives (Hart Publishing 2017).

71 The Court of Justice emphasised the importance of proportionality of precautionary measures by claiming that "in exercising their discretion relating to the protection of public health, the Member States must comply with the principle of proportionality" (Case C-88/07 Commission of the European Communities v Kingdom of Spain, ECLI:EU:C:2009:123, para 88; see also T-13//99 Pfizer Animal Health v Council, ECLI:EU:T:2002:209, paras 163 and 410-11). The Court also pointed to the importance of non-discrimination by stating that the "precautionary principle justifies the adoption of restrictive measures, provided they are non-discriminatory and objective" (Cases C-333/08 European Commission v French Republic, ECLI:EU:C:2010:44, para 93 and Case C-77/09 Gowan Comércio Internacional e Serviços Lda v Ministero della Salute, ECLI:EU:C:2010:803, para 76; C-446/08 Solgar Vitamin's France and Others $v$ Ministre de l'Économie, des Finances et de l'Emploi and Others, ECLI:EU:C:2010:233, para 70).

72 Communication from the Commission on the precautionary principle, $\operatorname{COM}(2000) 1$ final, para 6.

Despite its non-binding nature, the Commission Communication sets a valuable framework for the use of precautionary measures. For the contributions and the shortcomings of the Commission Communication, see JD Graham and S Hsia, "Europe's precautionary principle: Promise and pitfalls" (2002) 5(4) Journal of Risk Research 371-90. On the
} 
Decision-makers' choice of COVID-19 policies had to be in line with these criteria and it is questionable whether this was always the case. ${ }^{73}$

Satisfying the proportionality requirement of COVID-19 mobility restrictions is particularly problematic. This subsection aims to examine the proportionality of mobility restrictions and link the analysis to the findings about the use of the precautionary principle in COVID-19 mobility policies. It will be argued that reliance on precaution in the adoption of COVID-19 mobility restrictions transforms the application of the principle of proportionality, in particular its test of necessity, by lowering the standard of what is "necessary", due to the scientific uncertainty entailed within precautionary approach.

As explained in Section II, the imposed COVID-19 mobility restrictions consisted of two groups of measures: the reintroduction of internal border controls and various types of travel restrictions and bans on entry and exit to/from national territories. The Schengen Borders Code explicitly provides that internal border controls can be reintroduced only as last resort measures and only provided they fulfil the proportionality requirements, meaning that their scope and duration does not exceed what is strictly necessary to respond to the serious threat. ${ }^{74}$ Whereas the reintroduction of internal border checks probably satisfies the proportionality requirements, it is arguable whether the same could be claimed for all national travel restrictions and bans.

However, the precautionary nature of COVID-19 mobility restrictions (and of any other precautionary measure) transforms the proportionality analysis that has to be performed to check their compliance with EU law. This is due to the limited scope and uncertain character of evidence that was available to legislators imposing COVID-19 restrictions. Evaluating whether a particular travel ban is proportionate to the level of protection of human health it affords has to be assessed against a high degree of scientific uncertainty associated with the pandemic. It is relatively easy to argue that travel bans were suitable for the protection of public health, since they contributed to the reduction of the number of coronavirus infections by minimising the number of personal contacts and transmissions. However, the lack of reliable and certain scientific evidence that was available to decision-makers at the time of imposing restrictive measures renders the criterion of necessity much more flexible. Scientific uncertainty - inherent in any precautionary measure lowers the threshold that has to be satisfied when assessing the legality of the legislator's choice of the restrictive measure. The legislator is, thus, expected to look at the limited and uncertain scientific evidence that was available at the time of the decision and reasonably conclude that no less restrictive and equally effective measure could have been taken. Due to the uncertain effectiveness of different restrictive options, the legislator will be tolerated a higher level of discretion, as long as the choice of the measure is reasonable, considering other legislative choices. Consequently, scientific uncertainty associated with COVID-19

\footnotetext{
application of the criteria from the Communication in case-law, see MD Rogers, "Risk management and the record of the precautionary principle in EU case law" (2011) 14(4) Journal of Risk Research 467-84.

73 For the importance of learning a lesson from the COVID-19 pandemic and of making decision-makers accountable to the public for their departures from risk-regulatory principles, see A Alemanno, "Taming COVID-19 by Regulation: An Opportunity for Self-Reflection" (2020) 11(2) European Journal of Risk Regulation 187-94.

74 Art 25(1) and 25(2) of Schengen Borders Code.
} 
and with any other precautionary measure juxtaposes the precautionary principle and the principle of proportionality - while enabling the former, it transforms the latter, by requiring a lower degree of necessity.

One of the COVID-19 mobility measures that is problematic from the perspective of its proportionality (primarily on suitability and necessity grounds) is the creation of special border corridors. ${ }^{75}$ The way such mobility corridors were arranged, without sufficient regard to public health precautions, can be viewed as inconsistent with other COVID-19 mobility restrictions, thus challenging the suitability of those measures and departing from the general idea that free movement should temporarily be sacrificed for the benefit of public health. On the other hand, if it was possible to organise such mobility corridors while respecting all public health standards, one cannot but wonder why it would not be possible to do the same on a wider scale, calling into question the necessity of travel bans.

Further, the creation of "travel bubbles", whereby a group of states allow each other's citizens and residents to enter freely, could again in certain cases be problematic from the perspective of the principles of proportionality and non-discrimination. "Travel bubbles" are discriminatory in character, since they treat certain Member States and their nationals more favourably than others, but they can be justified and suitable, provided the Member States creating the bubble have similar and controllable coronavirus situations, by sharing similar, low rates of coronavirus infection. ${ }^{76}$ The Commission recognised this by stating that "where a Member State decides to allow travel into its territory or to specific regions and areas within its territory, it should do so in a non-discriminatory manner - allowing travel from all areas, regions or countries in the EU with similar epidemiological conditions", and continued that the lifting of restrictions must apply "without discrimination, to all EU citizens and to all residents of that Member State regardless of their nationality, and should be applied to all parts of the Union in a similar epidemiological situation". ${ }^{77}$ On the other hand, the creation of "travel bubbles" among Member States with different epidemiological situations, or allowing "travel bubbles" with only some Member States that share similar low rates of infection and not with others, would again not be suitable for the attainment of public health due to the inconsistency of the approach.

COVID-19 mobility restrictions also problematise the application of the third proportionality test: proportionality stricto sensu, which requires that the adopted restrictions are reasonable, considering other social interests and, therefore, necessitates a balancing exercise between the benefits to public health and the harm caused to free movement and other social interests. The balancing exercise, entailed within the principle of proportionality, is also contained within the political risk management part of the precautionary approach, whereby decision-makers have to

\footnotetext{
75 R Bejan, "COVID-19 and Disposable Migrant Workers”, Verffassungsblog (16 April 2020) < verfassungsblog.de/ covid-19-and-disposable-migrant-workers $>$ (last accessed 15 June 2020).

76 Such a "travel bubble" was created by the Baltic states on 15 May 2020 (see Euractiv, "Baltics open Europe's first pandemic 'travel bubble' as curbs ease" (15 May 2020) <www.euractiv.com/section/justice-home-affairs/news/balticsopen-europes-first-pandemic-travel-bubble-as-curbs-ease/> (last accessed 15 June 2020).

77 Communication from the Commission: Towards a phased and coordinated approach for restoring freedom of movement and lifting internal border controls: COVID-19, 2020/C 169/03, C/2020/3250, OJ C 169, 15.5.2020, pp 30-37.
} 
make a choice whether to act and how. The importance of balancing has been recognised in several EU COVID-19-related documents, when stating that "the decision to end restrictive measures is a multidimensional policy decision, involving balancing public health benefits against other social and economic impacts". ${ }^{78}$

The decision-makers' obligation to balance among different social interests shows that scientific data are just one - though an indispensable one - of the factors that determined the political choice of taking precautionary measures against COVID-19. When responding to the COVID-19 pandemic, political leaders had to balance a range of important considerations, human health being just one of them. Political decisions were made by taking into account a number of other factors, most important being the preservation of national healthcare systems against the risk of collapse due to limited healthcare capacities. In addition, they could not ignore the negative economic and social consequences of precautionary measures, as well as public health risks they created for the population, especially for the most vulnerable and older ones who became more susceptible to mental health problems caused by physical distancing and lockdowns and to other health problems caused by the postponement of medical examinations and treatments that did not require immediate and urgent attention.

Divergences in the choice of precautionary measures and their changes reflect not only alterations in the number of infections and mortality, but also the differences in the outcomes of the balancing exercise, influenced by states' economic and social endurance and healthcare capacities. For this reason it is not surprising that the initial COVID-19 policies in most Member States gave complete precedence to the protection of public health over economic and other social interests - in line with the case law on the precautionary principle - whereas subsequent approaches become more receptive towards the balancing of public health and other economic and social interests. ${ }^{79}$ It also means that a new COVID-19 wave of infections does not have to result in the same degree and type of travel restrictions and bans as the ones in winter/spring 2020. ${ }^{80}$ This opens up the question whether travel bans adopted so far were proportionate stricto sensu, considering the fact that their adoption and lifting were not always consistent with the alterations in the number of coronavirus infections in different Member States. Consequently, some Member States whose economies depend on tourism imposed more severe travel restrictions in winter/spring 2020, at the time when their coronavirus infections were relatively low in a number of Member States, lifted them later on and decided to keep them lifted in summer

\footnotetext{
78 Joint European Roadmap towards lifting COVID-19 containment measures, 2020/C 126/01, C/2020/2419, OJ C 126, 17 April 2020, pp 1-11, point 4.1.

79 According to the Court of Justice in Solvay Pharmaceuticals, the choice whether and what type of precautionary measures to take must "comply with the principle that the protection of public health, safety and the environment is to take precedence over economic interests" (Case T-392/02 Solvay Pharmaceuticals BV v Council of the European Union, ECLI identifier: ECLI:EU:T:2003:277, para 125).

80 According to the ECDC, the second wave of coronavirus infections is inevitable and it is only questionable when and how big the wave will be (Euractiv, "Not if but when': European health boss warns of virus second wave" (22 May 2020) <www.euractiv.com/section/coronavirus/news/not-if-but-when-european-health-boss-warns-of-virus-secondwave/?fbclid=IwAR24vA_s6VMxFi27Q45ApBalBEhoswNNiIqhs-70wEJdYdudxpGVNkMbZRQ > (last accessed 29 May 2020).
} 
2020, to promote their tourist season, despite a considerable increase in the number of infections.

Nevertheless, it has to be acknowledged that the balancing among different social interests in the COVID-19 circumstances was extremely burdensome for a number of reasons. First, it is generally difficult to make trade-offs and find a compromise between the protection of public health, on the one hand, and the protection of fundamental freedoms and rights that had to be restricted, on the other hand. Second, decisions were difficult because of the urgency caused by the high degree and speed of infectiveness of coronavirus and so many unknowns associated with it, and partly due to the difficulty of quantitatively measuring its effects when comparing different precautionary measures. Like the problems encountered with the performance of the test of necessity, the scientific uncertainty associated with COVID-19 also made the balancing exercise extremely challenging.

Third, the question whether travel bans were reasonable, considering other competing interests, might vary depending on how wealthy a society is and how long it can withstand the economic consequences of lockdowns. Changing attitudes to COVID19 have become visible in the past few months, in which the political rhetoric has turned from "we have to shut down for the virus" to "we have to dance with the virus". The answer to this question might also vary among EU Member States, based on their societal and cultural preferences, as different societies might have different expectations, fears and priorities. The ECDC has recognised the importance of respecting the level of societal tolerance of the anticipated COVID-19 risks by stating that "societal norms and values underpinning freedom of movement and travel will need to be weighed against precautionary principles and the public acceptance of risks", thus confirming the fact that "what may be acceptable and feasible in one setting may not be in another". ${ }^{81}$ In this context, one of the explanations for the Swedish response to the COVID-19 pandemic being much more relaxed than in the rest of Europe is based on the presumption that the level of social and institutional trust in Sweden is much higher than in most EU Member States, due to its historical, political, social and cultural mores. ${ }^{82}$ This, in effect, enabled Swedish decisionmakers to adopt measures which rested on individual responsibility and mutual trust, instead of strict lockdowns.

Finally, the understanding whether a particular COVID-19 mobility restriction is reasonable or not might also vary among different social groups, depending on what they perceive as a threat. For a retired 75-year-old person with chronic health problems, or any other individual belonging to a COVID-19 risk group, any measure which reduces the threat of coronavirus for his or her life and health might be reasonable, no matter what side effects. On the other hand, from the perspective of a

\footnotetext{
81 European Centre for Disease Prevention and Control, Considerations relating to social distancing measures in response to the COVID-19 epidemic (ECDC 2020) p 5. See also para 5.2.1. of the Commission Communication stating that "the appropriate response in a given situation is thus the result of an eminently political decision, a function of the risk level that is 'acceptable' to the society on which the risk is imposed".

82 L Trägårdh and U Özkirimli, "Why might Sweden's Covid-19 policy work? Trust between citizens and state", The Guardian, 21 April $2020<$ www.theguardian.com/world/commentisfree/2020/apr/21/sweden-covid-19-policy-trustcitizens-state\#maincontent $>$ (last accessed 29 May 2020). See also N Khorrami, "Sweden did it differently - but is it working?", EuObserver (6 May 2020) <euobserver.com/opinion/148260> (last accessed 29 May 2020).
} 
young and healthy individual who has lost his or her job or source of income from tourism or seasonal work, the costs of border closures might outweigh their benefits. In addition, one's past experience, geographical proximity to infected regions and increased media exposure of coronavirus may also influence individual preferences associated with COVID-19 mobility restrictions. ${ }^{83}$ As a result, one society, social group or individual might be willing to pay a higher cost to protect human health than another, which can, in effect, lead to different views on whether free movement restrictions are reasonable, thus influencing political choices of the types and degree of severity of the adopted restriction.

It has to be acknowledged that balancing among different social interests is not a peculiarity of COVID-19 mobility restrictions. On the contrary, balancing has to be performed by policy-makers every time they adopt a new measure and they are frequently confronted with diverse expectations from different social groups. However, in the COVID-19 circumstances, the balancing exercise is much more difficult than usual due to the severity, duration and scientific uncertainty associated with COVID-19 and due to the powerful impact of COVID-19 policies on our societies. It is not surprising that over time - as the side effects of precautionary measures are becoming more palpable and measurable - public attitudes towards the suitability, necessity and reasonableness of the adopted measures are becoming more and more divergent. In this context, political leaders will have the difficult task of defending the adopted measures both before the public and before courts.

\section{Conclusion}

Coronavirus has generated a public health emergency of great magnitude and severity, never previously encountered by the EU and worldwide. It has put into jeopardy not only human lives and health, but also the viability of our health systems, economies and societies. The pandemic has resulted in significant social and system shifts, including visible changes of EU law. This text aimed to discuss some of these legal changes, by focusing on the roles of public health restrictions, the precautionary principle and the principle of proportionality. The discussion has revealed that the EU has taken a precautionary approach towards the COVID-19 pandemic and that the implementation of the precautionary principle transforms the application of the principle of proportionality to COVID-19 mobility restrictions. The text has also shown that COVID-19 has altered our understanding of public health restrictions, due to the fact that it has certain characteristics which differentiate it from other infectious diseases we have known so far, and that it has, consequently, increased the difference between the conditions for the applicability of public health restrictions, when compared to public policy and public security restrictions.

\footnotetext{
83 For the discussion on the importance of taking into account values and socio-emotional issues that may be associated with risks, see International Risk Governance Council (IRGC), "Introduction to the IRGC Risk Governance Framework, revised version” (EPFL International Risk Governance Center 2017).
} 
The text has pointed to the challenges in finding the right balance between disease control and protection of fundamental freedoms, and between the level of health risks and societal risk tolerance. However, the weaknesses of COVID-19 mobility restrictions lie not only in the challenges they pose to the functioning of the EU internal market, but also in their inability to respond to the needs of contemporary societies and social cohesion. COVID-19 points to the need to prepare our public health systems for future pandemics and adjust our legal systems accordingly. 